$\$$ Research Square
Preprints are preliminary reports that have not undergone peer review.

They should not be considered conclusive, used to inform clinical practice, or referenced by the media as validated information.

\title{
The Different Outcomes Between Breast-Conserving Surgery plus Radiotherapy and Mastectomy in Metaplastic Breast Cancer: A Population-Based Study
}

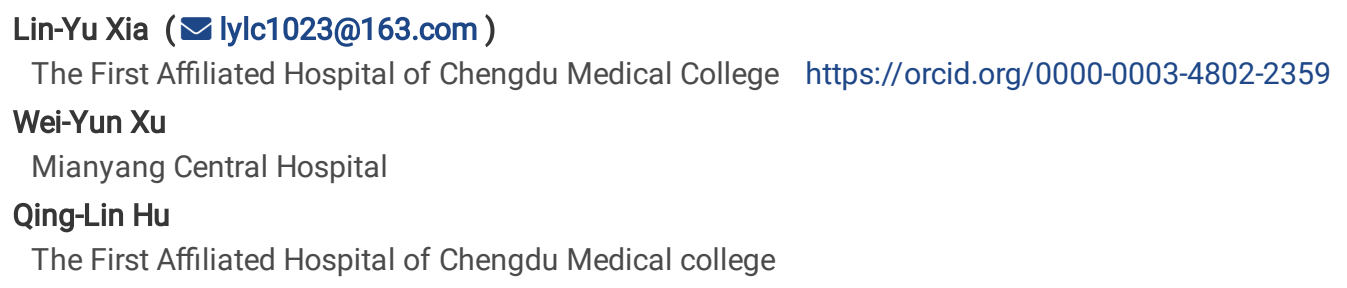

Research Article

Keywords: metaplastic breast cancer, breast-conserving surgery, radiotherapy, mastectomy, survival outcomes

Posted Date: February 23rd, 2021

DOI: https://doi.org/10.21203/rs.3.rs-241019/v1

License: (c) (i) This work is licensed under a Creative Commons Attribution 4.0 International License. Read Full License 


\section{Abstract}

Background: Metaplastic breast cancer (MBC) are rare. The survival outcomes of MBC patients after breast conserving surgery plus radiotherapy (BCS+RT) or mastectomy have not been established. The aim of this study was to compare survival outcomes of MBC patients subjected to BCS+RT or mastectomy therapeutic options.

Methods: Patients who were subjected to BCS+RT or mastectomy between 2004 and 2014 were enrolled in this study through the Surveillance, Epidemiology and End Results (SEER) database. Breast cancer-specific survival (BCSS) and the overall survival (OS) of the participants were determined. Cox proportional hazard model and Kaplan Meier method were used to determine the correlation between the two surgical methods and survival outcomes.

Results: A total of 1197 patients were enrolled in this study. Among them, 439 patients were subjected to BCS+RT, while 758 patients were subjected to mastectomy. Multivariate analysis showed a significantly high OS for MBC patients who were subjected to BCS+RT compared to those subjected to mastectomy $(\mathrm{HR}=0.697,95 \% \mathrm{Cl}=0.527-0.922, P=0.012)$. However, the BCSS for the two groups were statistically comparable $(\mathrm{HR}=0.806,95 \% \mathrm{Cl}=0.561-1.158, P=0.244)$. After PSM, the BCS+RT and mastectomy groups consisted of 321 patients, respectively. The univariate and multivariate analysis with a 6-month landmark all indicate that patients receiving BCS+RT has higher OS than patients receiving mastectomy $(\mathrm{HR}=0.701,95 \% \mathrm{Cl}=0.496-0.990, P=0.044 ; \mathrm{HR}=0.684,95 \% \mathrm{Cl}=0.479-0.977, P=0.037)$ while the $\mathrm{BCSS}$ was no difference between the two groups $(\mathrm{HR}=0.739,95 \% \mathrm{Cl}=0.474-1.153, P=0.183 ; \mathrm{HR}=0.741,95 \% \mathrm{Cl}=0.468-1.173, P=0.200)$.

Conclusion: The BCS+RT therapeutic option exhibits a high OS in MBC patients compared to the mastectomy approach.

\section{Introduction}

Metaplastic breast cancer (MBC) is a rare pathological type of breast cancer that is characterized by the presence of epithelial and mesenchymal components. It accounts for $1 \%-2 \%$ of all breast cancers [1, 2]. Compared with invasive ductal carcinoma, MBC tumors are often larger, less likely to have nodal metastasis, more likely to be hormone receptor and human epidermal growth factor receptor 2(HER 2) negative[3]. It's more aggressive and has a poor prognosis [4-6].MBC more commonly manifests as triple-negative disease, so endocrine therapy and targeted therapy are rarely used[7].The effect of chemotherapy may be limited, while radiotherapy has been proved to improve the prognosis of MBC [8,9].Surgical treatment is still one of the important treatment methods.

Currently, surgical therapeutic options for breast cancer include breast conserving surgery and total mastectomy. Several studies have reported that BCS + RT exhibit the same survival outcomes as mastectomy [10-13]. However, given the aggressive and poor MBC prognosis, it is not certain whether a more aggressive locoregional approach is necessary. Few MBC patients are subjected to BCS when compared to the number subjected to mastectomy [2,14]. Notably, there are no specific MBC treatment guidelines and consensus because it is a rare type of cancer. In addition, the prognosis of MBC patients after being subjected to BCS+RT and mastectomy has not been widely reported and neither has it been established [15]. In this study, we compared the OS and BCSS of MBC patients who had been subjected to BCS+RT and mastectomy.

\section{Material And Methods}

\section{Patients}

This retrospective study was conducted using the SEER database published in November 2018 and contains data from 18 population-based cancer registries.

Patients diagnosed with metaplastic breast cancer from 2004 to 2014 were collected. Other inclusion criteria included: (1) female; (2) 20-79 years old; (3) T1-3N0-3M0; (4) A mastectomy or breast-conserving surgery was performed. Exclusion criteria included :(1) prophylactic mastectomy was performed; (2) patients with unknown clinical and pathological characteristics; (3) patients without radiotherapy after breast conserving surgery.

We collected the following clinical and pathological features: age and year of diagnosis, race, marital status, histological grade, tumor size ( $T$ stage), lymph node status, ER, PR, surgical method, postoperative chemotherapy and radiotherapy.

\section{Outcome measures and Statistical analysis}

Our main outcomes of interest was OS and BCSS,OS were calculated from the date of diagnosis to the date of death and the BCSS were calculated from the date of diagnosis to the date of death due to breast cancer.

In order to reduce the selection bias and achieve balance covariates across treatment groups we created a matched dataset using one-to-one (1:1) PSM [16,17]. The conditional landmark analysis was used to address an lead time bias among the propensity matched cohort [18]. With the 
landmark, analysis was restricted to the patients who survived to 6 months without death or loss to follow-up.

We compared the clinicopathological characteristics of the two groups of patients before and after PSM through the $\mathrm{X}^{2}$ test, The survival curve was plotted through the Kaplan-Meier product limit method and compared by the log rank test. A Cox proportional hazards regression model was used for the univariate and multivariate analyses of BCSS and OS.All $P$ values were two-sided, and $P<0.05$ was considered to be statistically significant. These analyses were performed using the SPSS version 20.0 software package (IBM SPSS Statistics, Chicago, IL, US).

\section{Ethics statement}

This study obtained data from the SEER database, so informed consent is not required.

\section{Results}

\section{General characteristics of the study population and tumor}

A total of 1197 patients were enrolled in the study through the SEER database. Participants were allocated into two groups based on the surgical method. They were subjected to: the BCS+RT group $(439,36.68 \%)$ and the mastectomy group $(758,63.32 \%)$. Patients in the BCS+RT group showed smaller tumors $(P<0.001)$, fewer lymph node metastases $(P<0.001)$, and a higher PR negative rate compared to patients in the mastectomy group $(P<0.05)$. Moreover, the odds of chemotherapy and radiotherapy administration to patients in the BCS+RT group was significantly high compared to those in the mastectomy group $(P<0.001)$.Considering the different between case and control groups. We used PSM to construct a matched sample consisting of 321 pairs of BCS+RT and mastectomy subjects. There were no difference between the variables of the two groups after PSM.Table 1 shows the demographic and clinicopathological characteristics of the two groups.

\section{Comparison of BCSS and OS Between BCS+RT and mastectomy groups}

To determine the effectiveness of the two surgical procedures, OS and BCSS in patients who had been subjected to BCS + RT and mastectomy were compared. Before PSM,the median follow-up time was 56 months. Among patients in the BCS + RT group, Kaplan-Meier analysis showed a significantly high OS and BCSS when compared to those in the mastectomy group (all log-rank $P<0.05$,Figure 1). The 5-year OS for patients who had been subjected to BCS+RT and mastectomy were $85.1 \%$ and $67.7 \%$, while the 10 -year OS for patients in the two groups were $77.1 \%$ and $55.5 \%$, respectively. The 5-year BCSS for patients who had been subjected to BCS+RT and mastectomy were $90.2 \%$ and $78.7 \%$, while the 10 -year BCSS were $86.5 \%$ and $76.3 \%$, respectively.After PSM with a 6 months landmark, Patients in the BCS + RT group showed a significantly high OS outcomes compared to patients in the mastectomy group(log-rank $P=0.042$, Figure $2 \mathrm{~A}$ ), while patients in the two subjects had similar BCSS(logrank $P=0.181$, Figure $2 \mathrm{~B}$ ). The 5-year OS for the group with BCS + RT was $84.6 \%$ and was $78.7 \%$ in the mastectomy group,while the 10 -year OS for patients in the two groups were $75.1 \%$ and $66.7 \%$.Similar 5-year and 10-year BCSS were found for the two groups (5-year:BCS + RT,89.6\% vs. mastectomy, 85.0\%;10-year:BCS + RT,85.0\% vs. mastectomy, 83.6\%).

\section{Prognostic factors associated with OS and BCSS}

Before PSM, multivariate cox regression analysis showed that larger tumors and more lymph node metastases were associated with poor BCSS and OS. Chemotherapy ( $\mathrm{HR}=1.968,95 \% \mathrm{Cl}=1.538-2.517, P<0.001)$ and $\mathrm{BCS}+\mathrm{RT}(\mathrm{HR}=0.697,95 \% \mathrm{Cl}=0.527-0.922, P=0.012)$ were only associated with improved OS, but not BCSS(Table 2).After PSM, the results of multivariate cox regression analysis, with a 6-month landmark showed that factors associated with OS and BCSS were same as the fators before PSM.Patients who had larger tumors and more lymph node metastases showed poor BCSS and OS.Surgical type and chemotherapy are independent OS prognostic factors.Patients in the BCS + RT group showed a significantly high OS outcomes compared to patients in the mastectomy group $(\mathrm{HR}=0.684,95 \% \mathrm{Cl}=0.479-0.977, P=0.037)$. Patients who were not administered with chemotherapy showed low OS compared to those who had received chemotherapy $(\mathrm{HR}=2.253,95 \% \mathrm{Cl}=1.457-$ $3.485, P<0.001)($ Table 3).

\section{Stratified analysis of OS and BCSS}

A stratified analysis of all patients after PSM was performed to determine the possible factors affecting the overall survival time for patients who had been subjected to the two types of surgical procedures. Stratified analysis was based on age, diagnostic year, race, marital status, histological grade, tumor size (T stage), lymph node status, ER, PR, surgical methods and postoperative chemotherapy (Table 4). After adjusting for the important prognostic variables in the univariate analysis, the multivariate analysis showed significantly high OS when BCS+RT was given to patients aged between 20-49 years, the white race group,patients with grade III+IV, patients with T2, patients with ER positive and those who received chemotherapy(See Supplementary Figure 1, Additional File 1).No factors were associated with the BCSS of patients who received BCS+RT.

\section{Discussion}


The prognosis of MBC patients after after being subjected to BCS + RT and mastectomy has not been established. We found that patients subjected to BCS + RT exhibited better OS outcomes when compared to patients who had been subjected to mastectomy. Furthermore, patients who had been subjected to BCS+RT exhibited improved OS outcomes in the young, white race, grade III+IV, T2, ER positive and chemotherapy subgroups. The OS and BCSS outcomes of mastectomy were not better than those of BCS + RT in any stratification.

In our study, before PSM,80.87\% of the MBC cases were classified as grade III. Most of the cases were negative for ER and PR (81.12\%, $85.63 \%$ ). A low positive rate of axillary lymph nodes were observed in this study, a finding that is in tandem with previous findings (20.72\%) [19,20]. This finding indicates poor MBC prognosis. Due to poor tumor grade, invasiveness, and the large size of most tumors, most clinicians advocate for aggressive total mastectomy. Previous studies have documented that MBC patients who are subjected to BCS and mastectomy exhibit similar prognosis [15].

In this study, the OS outcomes for the BCS + RT group was significantly high when compared to that of the mastectomy group. However, the BCSS outcomes of the two groups were statistically comparable. Stratified analysis showed that the BCS + RT group had significantly high OS outcomes when compared to the mastectomy group. Notably, the OS and BCSS outcomes of the mastectomy group was lower than those of the BCS + RT group. These findings were contrary to those of Dave et al [15] who reported that the BCS and the mastectomy group had statistically similar 5 -year local recurrence-free rate ( $88 \%$ vs. $85 \%, P=0.86)$, disease-free rate $(55 \%$ vs. $84 \%, P=0.13)$, and overall survivals $(80 \%$ vs. $89 \%, P=$ 0.58). The differences in these findings could be attributed to the fact that all BCS patients enrolled in our study were subjected to postoperative radiotherapy. Postoperative radiotherapy rate for BCS patients in the study of Dave et al was $86.36 \%$. Postoperative radiotherapy in BCS patients inhibits local recurrence and improves the overall survival rate [8,21]. In addition, a recent study showed that postoperative breast-conserving radiotherapy significantly improved the OS outcomes for MBC patients compared to the OS outcomes for MBC patients who had not been administered with radiotherapy (5-year OS: $85 \%$ vs $61 \%$, 10 -year OS: $67 \%$ vs $49 \%, P<0.001$ ) [19]. The differences in these findings could be attributed to sample size variations among the studies.

The poor prognosis of MBC patients is significantly correlated with tumor size and lymph node metastasis, consistent with study findings of Chao et al [22]. This study, as other studies, established that tumor grade and hormone receptor status were not correlated with MBC prognosis $[23,24]$. A previous study documented that the OS outcomes of patients who had been administered with chemotherapy was better compared to the OS of patients who had not been administered with chemotherapy [25]. Studies have also documented that chemotherapy does not improve the OS of MBC patients because MBC is resistant to chemotherapy [26,27]. In this study, after PSM,patients who were not administered with chemotherapy showed low OS compared to those who had received chemotherapy $(\mathrm{HR}=2.253,95 \% \mathrm{Cl}=1.457-3.485, P<0.001)$.So we think that chemotherapy is effective for MBC. Before PSM,we observed that $30.61 \%$ of the patients in the mastectomy group were subjected to radiotherapy after surgery. This is because $74.27 \%$ of the patients in the mastectomy group had no lymph node metastases. Compared to lymphatic metastasis, MBC is highly associated with blood metastasis, therefore, the rate of lymph node metastasis in MBC patients is low [5].

Our study has some limitations. Firstly,despite the use of propensity matched landmark analysis, there may be residual confounding factors.secondly, since the SEER database has only recorded the status of HER2 since 2010, there are too many unknown cases, so we did not collect the status of HER2. Finally, the SEER database has no records on endocrine therapy and targeted therapy, so we did not study the effects of endocrine therapy and targeted therapy on OS and BCSS.

\title{
Conclusion
}

In conclusion, this population-based study based on SEER database showed that the OS of MBC patients receiving BCS + RT was significantly better than that of patients receiving mastectomy. Compared with mastectomy, BCS + RT can not only bring better cosmetic effect, but also predict a better prognosis. Therefore, we believe that BCS + RT may be the best local treatment for MBC patients, but prospective studies are still needed to further verify our conclusions.

\section{Abbreviations}

$\mathrm{MBC}=$ Metaplastic breast cancer

$\mathrm{BCS}+\mathrm{RT}=$ Breast conserving surgery plus radiotherapy

OS= overall survival

BCSS = breast cancer-specific survival

\section{Declarations}

\author{
- Acknowledgments
}

Page $4 / 13$ 
Not applicable.

\section{- Funding}

Not applicable.

\section{- Availability of data and materials}

Surveillance, Epidemiology, and End Results (SEER) Program (www.seer.cancer.gov)

SEER*Stat Database: Incidence - SEER 18 Regs Custom Data (with additional treatment fields), Available at: https://seer. cancer.gov/data/, Accessed June 13, 2019.

\section{- Authors' Contributions}

Protocol/project development: L.-Y.X and Q.-L.H. Data acquisition and interpretation of data:L.-Y.X. Statistics analysis of data: L.-Y.X and W.-Y.X Manuscript drafting: L.-Y.X and W.-Y.X. Manuscript Revision and accountable for all aspects of the study:L.-Y.X and Q.-L.H. All authors read and approved the final manuscript.

\section{- Ethics approval and consent to participate}

Not applicable.

\section{- Consent to publish}

Not applicable.

\section{- Conflict of Interest}

The author(s) declare that they have no competing interests. The authors declare that the research was conducted in the absence of any commercial or financial relationships that could be construed as a potential conflict of interest.

\section{References}

1. Siegel RL, Miller KD, Jemal A. Cancer statistics, 2018. CA Cancer J Clin. 2018;68(1):7-30.

2. Pezzi CM, Patel-Parekh L, Cole K, Franko J,Klimberg S,Bland K,et al. Characteristics and treatment of metaplastic breast cancer: analysis of 892 cases from the National Cancer Data Base. Ann Surg Oncol.2007; 14: 166-173.

3. Jung SY, Kim HY, Nam BH,Min SY, Lee SJ,Park C, et al. Worse prognosis of metaplastic breast cancer patients than other patients with triplenegative breast cancer. Breast Cancer Res Treat. 2010; 120: 627-637.

4. Luini A, Aguilar M, Gatti G, Fasani R, Botteri E, JBrito JAD ,et al. Metaplastic carci-noma of the breast, an unusual disease with worse prognosis: the experience of the European Institute of Oncology and review of the literature. Breast Cancer Res Treat.2007;101:349-353.

5. McKinnon E, Xiao P. Metaplastic carcinoma of the breast. Arch Pathol Lab Med. 2015; 139: 819-822.

6. Lee H, Jung SY, Ro JY, Kwon Y, Sohn JH, Park IH,et al. Metaplastic breast cancer: clinicopathological features and its prognosis. J Clin Pathol. 2012;65(5):441-446.

7. Zhang Y, Lv F, Yang Y,Qian X,Lang R, Fan Y, et al. Clinicopathological Features and Prognosis of Metaplastic Breast Carcinoma: Experience of a Major Chinese Cancer Center. PLoS One. 2015; 10: e0131409.

8. Tseng WH, Martinez SR. Metaplastic breast cancer: to radiate or not to radiate? Ann Surg Oncol. 2011;18:94-103.

9. Chen IC, Lin CH, Huang CS, Lien HC, Hsu C, Kuo WH, et al. Lack of efficacy to systemic chemotherapy for treatment of metaplastic carcinoma of the breast in the modern era. Breast Cancer Res Treat. 2011; 130: 345-351.

10. Fisher B, Anderson S, Bryant J, MARGOLESE RG, DEUTSCH MV, FISHER ER,et al. Twenty-year follow-up of a randomized trial comparing total mastectomy, lumpectomy, and lumpectomy plus irradiation for the treatment of invasive breast cancer. N Engl J Med. 2002; 347: 12331241.

11. Abdulkarim BS, Cuartero J, Hanson J, Deschenes J, Lesniak D, Sabri S. Increased risk of locoregional recurrence for women with T1-2N0 triple-negative breast cancer treated with modified radical mastectomy without adjuvant radiation therapy compared with breast-conserving therapy. J Clin Oncol. 2011;29:2852-2858.

12. Early Breast Cancer Trialists' Collaborative Group (EBCTCG). Effect of radiotherapy after breast-conserving surgery on 10-year recurrence and 15-year breast cancer death: meta-analysis of individual patient data for 10,801 women in 17 randomised trials. Lancet. 2011;378:17071716. 
13. van Maaren MC, de Munck L, de Bock GH, Jobsen JJ, van Dalen T, Linn SC, et al. 10 year survival after breast-conserving surgery plus radiotherapy compared with mastectomy in early breast cancer in the Netherlands: a population-based study. The Lancet Oncology. 2016;17:1158-1170.

14. Nelson RA, Guye ML, Luu T, Lai LL. Survival outcomes of metaplastic breast cance-r patients: results from a US populationbased analysis. Ann Surg Oncol. 2015;22:24-31.

15. Dave G, Cosmatos H, Do T, Lodin, K, Varshney D. Metaplastic carcinoma of the bre-ast: A retrospective review.International Journal of Radiation Oncology*Biology*Physics.2006; 64(3), 771-775.

16. D'Agostino RJ. Propensity score methods for bias reduction in the comparison of a treatment to a non-randomized control group. Stat Med. 1998;17(19):2265-281.

17. Austin PC. The use of propensity score methods with survival or time-to-event outcomes: reporting measures of effect similar to those used in randomized experiments. Stat Med. 2014;33(7):1242-1258.

18. Giobbie-Hurder A, Gelber RD, Regan MM. Challenges of guarantee-time bias. J Clin Oncol. 2013;31(23):2963-2969.

19. Haque W, Verma V, Naik N, Butler EB, Teh BS.Metaplastic Breast Cancer: Practice Patterns, Outcomes, and the Role of Radiotherapy. Annals of Surgical Oncology.2018;25(4), 928-936.

20. Rayson D, Adjei AA, Suman VJ,Wold LE, Ingle JN. Metaplastic breast cancer: Progn-osis and response to chemotherapy. Ann Oncol.1999;10:413-419.

21. Nowara E, Drosik A, Samborska-Plewicka M,Nowara EM, Stanek-Widera A. Metaplas-tic breast carcinomas analysis of prognostic factors in a case series. Contemp Oncol (Pozn). 2014; 18: 116-119.

22. Chao TC, Wang CS, Chen SC,Chen M. Metaplastic carcinomas of the breast. J Surg Oncol. 1999;71:220-225.

23. Rakha EA,Tan PH,Varga Z, Tse GM,Shaaban AM , Climent F, et al. Prognostic fact-ors in metaplastic carcinoma of the breast: a multiinstitutional study. Br J Cancer. 2015; 112: 283-289.

24. Paul Wright G,Davis AT, Koehler TJ,Melnik MK,Chung MH. Hormone receptor status does not affect prognosis in metaplastic breast cancer: a population-based analysis with comparison to infiltrating ductal and lobular carcinomas. Ann Surg Oncol.2014; 21: 3497-3503.

25. Cimino-Mathews A, Verma S, Figueroa-Magalhaes MC, Jeter SC,Zhang Z,Argani P,et al. A Clinicopathologic Analysis of 45 Patients With Metaplastic Breast Carcinoma. Am J Clin Pathol. 2016;145(3):365-372.

26. Kaufman MW, Marti JR, Gallager HS. Carcinoma of the breast with pseudosarcomato-us metaplasia. Cancer. 1984; 53:1908-1917.

27. Beatty JD, Atwood M, Tickman R. Metaplastic breast cancer: Clinical significance. Am J Surg. 2006; 191:657-664.

\section{Tables}

Table 1 Baseline characteristics of the study population and tumor 


\begin{tabular}{|c|c|c|c|c|c|c|c|}
\hline \multirow[t]{2}{*}{ Characteristics } & & \multicolumn{3}{|l|}{ before PSM } & \multicolumn{3}{|l|}{ after PSM } \\
\hline & & BCS+RT $(n, \%)$ & Mastectomy $(\mathrm{n}, \%)$ & $P$ & $\mathrm{BCS}+\mathrm{RT}(\mathrm{n}, \%)$ & Mastectomy $(\mathrm{n}, \%)$ & $P$ \\
\hline No. of patients & & $439(36.68 \%)$ & 758(63.32\%) & & 321 & 321 & \\
\hline \multirow[t]{2}{*}{ Year of diagnosis } & 2004-2009 & 195(44.42\%) & $328(43.27 \%)$ & 0.7 & $135(42.1 \%)$ & 134(41.7\%) & 0.936 \\
\hline & 2010-2014 & $244(55.58 \%)$ & $430(56.73 \%)$ & & $186(57.9 \%)$ & 187(58.3\%) & \\
\hline \multirow[t]{2}{*}{ Age (years) } & $20-49$ & 102(23.23\%) & 181(23.88\%) & 0.8 & $80(24.9 \%)$ & $72(22.4 \%)$ & 0.458 \\
\hline & $50-80$ & $337(76.77 \%)$ & $577(76.12 \%)$ & & $241(75.1 \%)$ & $249(77.6 \%)$ & \\
\hline \multirow[t]{3}{*}{ Race } & White & $336(76.54 \%)$ & $563(74.27 \%)$ & 0.121 & $256(79.8 \%)$ & $262(81.6 \%)$ & 0.189 \\
\hline & Black & $79(18 \%)$ & 129(17.02\%) & & $50(15.6 \%)$ & $37(11.5 \%)$ & \\
\hline & Other & $24(5.47 \%)$ & $66(8.71 \%)$ & & $15(4.7 \%)$ & $22(6.9 \%)$ & \\
\hline \multirow[t]{2}{*}{ Marital status } & Married & $271(61.73 \%)$ & $441(58.18 \%)$ & 0.228 & $205(63.9 \%)$ & $206(64.2 \%)$ & 0.934 \\
\hline & Not married & 168(38.27\%) & $317(41.82 \%)$ & & 116(36.1\%) & 115(35.8\%) & \\
\hline \multirow[t]{4}{*}{ Grade } & 1 & $16(3.64 \%)$ & $18(2.37 \%)$ & 0.098 & $5(1.6 \%)$ & $7(2.2 \%)$ & 0.313 \\
\hline & II & $66(15.03 \%)$ & $85(11.21 \%)$ & & $31(9.7 \%)$ & $33(10.63 \%)$ & \\
\hline & III & $344(78.36 \%)$ & 624(82.32\%) & & $278(86.6 \%)$ & $266(82.9 \%)$ & \\
\hline & IV & $13(2.96 \%)$ & $31(4.22 \%)$ & & $7(2.2 \%)$ & $15(4.7 \%)$ & \\
\hline \multirow[t]{3}{*}{ Tumor size $(\mathrm{cm})$} & $<2$ & 183(41.69\%) & 150(19.79\%) & $<0.001$ & 103(32.1\%) & 106(33.0\%) & 0.959 \\
\hline & $\geqq 2$ and $<5$ & $238(54.21 \%)$ & $431(56.86 \%)$ & & $201(62.6 \%)$ & 199(62.0\%) & \\
\hline & $\geqq 5$ & $18(4.1 \%)$ & 177(23.35\%) & & $17(5.3 \%)$ & $16(5.0 \%)$ & \\
\hline \multirow[t]{4}{*}{ Nodal status } & NO & 386(87.93\%) & $563(74.27 \%)$ & $<0.001$ & $275(85.7 \%)$ & $270(84.1 \%)$ & 0.509 \\
\hline & $\mathrm{N} 1$ & $46(10.48 \%)$ & 129(17.02\%) & & $41(12.8 \%)$ & $41(12.8 \%)$ & \\
\hline & N2 & $4(0.91 \%)$ & $40(5.28 \%)$ & & $3(0.9 \%)$ & $8(2.5 \%)$ & \\
\hline & N3 & $3(0.68 \%)$ & $26(3.43 \%)$ & & $2(0.6 \%)$ & $2(0.6 \%)$ & \\
\hline \multirow[t]{2}{*}{ ER } & Negative & $349(79.5 \%)$ & 622(82.06\%) & 0.276 & $264(82.2 \%)$ & $262(81.6 \%)$ & 0.837 \\
\hline & Positive & $90(20.5 \%)$ & 136(17.94\%) & & $57(17.8 \%)$ & $59(18.4 \%)$ & \\
\hline \multirow[t]{2}{*}{ PR } & Negative & $364(82.92 \%)$ & $661(87.2 \%)$ & 0.042 & $280(87.2 \%)$ & 282(87.9\%) & 0.811 \\
\hline & Positive & 75(17.08\%) & $97(12.8 \%)$ & & $41(12.8 \%)$ & $39(12.1 \%)$ & \\
\hline \multirow[t]{2}{*}{ Chemotherapy } & yes & $334(76.08 \%)$ & $529(69.79 \%)$ & 0.019 & $247(76.9 \%)$ & $251(78.2 \%)$ & 0.705 \\
\hline & no & 105(23.92\%) & $229(30.21 \%)$ & & $74(24.1 \%)$ & $70(21.8 \%)$ & \\
\hline \multirow[t]{2}{*}{ Radiotherapy } & yes & $439(100 \%)$ & 232(30.61\%) & & $311(100 \%)$ & $73(23.5 \%)$ & \\
\hline & no & $0(0 \%)$ & $526(69.39 \%)$ & & $0(0 \%)$ & 238(76.5\%) & \\
\hline
\end{tabular}

$\mathrm{PSM}=$ propensity score matching; $\mathrm{BCS}+\mathrm{RT}=$ Breast conserving surgery plus radiotherapy

Table 2 Prognostic factors for OS and BCSS in univariate and multivariate analysis 


\begin{tabular}{|c|c|c|c|c|c|c|c|c|c|}
\hline \multirow[t]{2}{*}{ Characteristics } & & \multicolumn{4}{|l|}{ OS } & \multicolumn{4}{|l|}{ BCSS } \\
\hline & & Univariate & $P$ & Multivariate & $P$ & Univariate & $P$ & Multivariate & $P$ \\
\hline \multirow{2}{*}{$\begin{array}{l}\text { Year of } \\
\text { diagnosis }\end{array}$} & 2004-2009 & Ref. & Ref. & Ref. & Ref. & Ref. & Ref. & Ref. & Ref. \\
\hline & $2010-2014$ & $\begin{array}{l}1.001(0.794- \\
1.261)\end{array}$ & 0.996 & $\begin{array}{l}1.015(0.801- \\
1.287)\end{array}$ & 0.903 & $\begin{array}{l}0.993(0.740- \\
1.333)\end{array}$ & 0.963 & $\begin{array}{l}0.950(0.702- \\
1.287)\end{array}$ & 0.741 \\
\hline \multirow[t]{2}{*}{ Age (years) } & $20-49$ & Ref. & Ref. & Ref. & Ref. & Ref. & Ref. & Ref. & Ref. \\
\hline & $50-80$ & $\begin{array}{l}1.465(1.113- \\
1.928)\end{array}$ & 0.007 & $\begin{array}{l}1.556(1.170- \\
2.069)\end{array}$ & 0.052 & $\begin{array}{l}0.929(0.674- \\
1.281)\end{array}$ & 0.653 & $\begin{array}{l}1.189(0.852- \\
1.658)\end{array}$ & 0.310 \\
\hline \multirow[t]{3}{*}{ Race } & White & Ref. & Ref. & Ref. & Ref. & Ref. & Ref. & Ref. & Ref. \\
\hline & Black & $\begin{array}{l}1.420(1.086- \\
1.855)\end{array}$ & 0.067 & $\begin{array}{l}1.301(0.988- \\
1.712)\end{array}$ & 0.061 & $\begin{array}{l}1.170(0.807- \\
1.695)\end{array}$ & 0.407 & $\begin{array}{l}1.041(0.712- \\
1.521)\end{array}$ & 0.837 \\
\hline & Other & $\begin{array}{l}1.418(0.964- \\
2.087)\end{array}$ & 0.084 & $\begin{array}{l}1.424(0.965- \\
2.102)\end{array}$ & 0.075 & $\begin{array}{l}1.294(0.771- \\
2.170)\end{array}$ & 0.330 & $\begin{array}{l}1.265(0.751- \\
2.130)\end{array}$ & 0.378 \\
\hline \multirow[t]{2}{*}{ Marital status } & Married & Ref. & Ref. & Ref. & Ref. & Ref. & Ref. & Ref. & Ref. \\
\hline & Not married & $\begin{array}{l}1.274(1.025- \\
1.583)\end{array}$ & 0.029 & $\begin{array}{l}0.948(0.754- \\
1.192)\end{array}$ & 0.650 & $\begin{array}{l}1.103(0.827- \\
1.472)\end{array}$ & 0.504 & $\begin{array}{l}0.916(0.675- \\
1.242)\end{array}$ & 0.571 \\
\hline \multirow[t]{4}{*}{ Grade } & 1 & Ref. & Ref. & Ref. & Ref. & Ref. & Ref. & Ref. & Ref. \\
\hline & ॥ & $\begin{array}{l}1.620(0.633- \\
4.141)\end{array}$ & 0.314 & $\begin{array}{l}1.246(0.483- \\
3.212)\end{array}$ & 0.649 & $\begin{array}{l}1.754(0.401- \\
7.669)\end{array}$ & 0.456 & $\begin{array}{l}1.228(0.278- \\
5.419)\end{array}$ & 0.786 \\
\hline & III & $\begin{array}{l}2.084(0.860- \\
5.048)\end{array}$ & 0.104 & $\begin{array}{l}1.404(0.571- \\
3.452)\end{array}$ & 0.460 & $\begin{array}{l}3.071(0.761- \\
12.384)\end{array}$ & 0.115 & $\begin{array}{l}1.579(0.385- \\
6.483)\end{array}$ & 0.526 \\
\hline & IV & $\begin{array}{l}3.209(1.204- \\
8.552)\end{array}$ & 0.020 & $\begin{array}{l}2.071(0.765- \\
5.606)\end{array}$ & 0.152 & $\begin{array}{l}4.422(0.980- \\
19.950)\end{array}$ & 0.053 & $\begin{array}{l}2.415(0.527- \\
11.079)\end{array}$ & 0.257 \\
\hline \multirow{3}{*}{$\begin{array}{l}\text { Tumor size } \\
(\mathrm{cm})\end{array}$} & $<2$ & Ref. & Ref. & Ref. & Ref. & Ref. & Ref. & Ref. & Ref. \\
\hline & $\geqq 2$ and $<5$ & $\begin{array}{l}1.975(1.439- \\
2.712)\end{array}$ & $<0.001$ & $\begin{array}{l}1.906(1.372- \\
2.649)\end{array}$ & $<0.001$ & $\begin{array}{l}3.124(1.893- \\
5.154)\end{array}$ & $<0.001$ & $\begin{array}{l}2.731(1.633- \\
4.567)\end{array}$ & $<0.001$ \\
\hline & $\geqq 5$ & $\begin{array}{l}5.555(3.953- \\
7.805)\end{array}$ & $<0.001$ & $\begin{array}{l}4.567(3.134- \\
6.655)\end{array}$ & $<0.001$ & $\begin{array}{l}9.668(5.750- \\
16.253)\end{array}$ & $<0.001$ & $\begin{array}{l}6.739(3.840- \\
11.828)\end{array}$ & $<0.001$ \\
\hline \multirow[t]{4}{*}{ Nodal status } & NO & Ref. & Ref. & Ref. & Ref. & Ref. & Ref. & Ref. & Ref. \\
\hline & N1 & $\begin{array}{l}1.713(1.292- \\
2.270)\end{array}$ & $<0.001$ & $\begin{array}{l}1.503(1.120- \\
2.017)\end{array}$ & 0.007 & $\begin{array}{l}2.213(1.554- \\
3.152)\end{array}$ & $<0.001$ & $\begin{array}{l}1.710(1.184- \\
2.470)\end{array}$ & 0.004 \\
\hline & N2 & $\begin{array}{l}3.550(2.345- \\
5.374)\end{array}$ & $<0.001$ & $\begin{array}{l}2.912(1.892- \\
4.483)\end{array}$ & $<0.001$ & $\begin{array}{l}4.959(3.048- \\
8.066)\end{array}$ & $<0.001$ & $\begin{array}{l}3.490(2.091- \\
5.825)\end{array}$ & $<0.001$ \\
\hline & N3 & $\begin{array}{l}4.792(3.026- \\
7.590)\end{array}$ & $<0.001$ & $\begin{array}{l}3.864(2.341- \\
6.378)\end{array}$ & $<0.001$ & $\begin{array}{l}6.107(3.498- \\
10.661)\end{array}$ & $<0.001$ & $\begin{array}{l}3.892(2.119- \\
7.147)\end{array}$ & $<0.001$ \\
\hline \multirow[t]{2}{*}{ ER } & Positive & Ref. & Ref. & Ref. & Ref. & Ref. & Ref. & Ref. & Ref. \\
\hline & Negative & $\begin{array}{l}1.195(0.886- \\
1.611)\end{array}$ & 0.243 & $\begin{array}{l}1.221(0.865- \\
1.723)\end{array}$ & 0.256 & $\begin{array}{l}1.076(0.739- \\
1.567)\end{array}$ & 0.702 & $\begin{array}{l}1.211(0.780- \\
1.881)\end{array}$ & 0.394 \\
\hline \multirow[t]{2}{*}{ PR } & Positive & Ref. & Ref. & Ref. & Ref. & Ref. & Ref. & Ref. & Ref. \\
\hline & Negative & $\begin{array}{l}1.290(0.917- \\
1.817)\end{array}$ & 0.144 & $\begin{array}{l}1.073(0.725- \\
1.588)\end{array}$ & 0.725 & $\begin{array}{l}1.097(0.720- \\
1.670)\end{array}$ & 0.668 & $\begin{array}{l}0.892(0.548- \\
1.453)\end{array}$ & 0.647 \\
\hline \multirow[t]{2}{*}{ Chemotherapy } & yes & Ref. & Ref. & Ref. & Ref. & Ref. & Ref. & Ref. & Ref. \\
\hline & no & $\begin{array}{l}1.535(1.225- \\
1.924)\end{array}$ & $<0.001$ & $\begin{array}{l}1.968(1.538- \\
2.517)\end{array}$ & $<0.001$ & $\begin{array}{l}0.789(0.560- \\
1.112)\end{array}$ & 0.176 & $\begin{array}{l}1.165(0.806- \\
1.684)\end{array}$ & 0.416 \\
\hline \multirow[t]{2}{*}{$\begin{array}{l}\text { Surgical } \\
\text { method }\end{array}$} & $\mathrm{BCS}+\mathrm{RT}$ & $\begin{array}{l}0.413(0.318- \\
0.535)\end{array}$ & $<0.001$ & $\begin{array}{l}0.697(0.527- \\
0.922)\end{array}$ & 0.012 & $\begin{array}{l}0.452(0.324- \\
0.632)\end{array}$ & $<0.001$ & $\begin{array}{l}0.806(0.561- \\
1.158)\end{array}$ & 0.244 \\
\hline & Mastectomy & Ref. & Ref. & Ref. & Ref. & Ref. & Ref. & Ref. & Ref. \\
\hline
\end{tabular}


OS= overall survival; BCSS = breast cancer-specific survival

Table 3 Prognostic factors for OS and BCSS in univariate and multivariate analysis after PSM 


\begin{tabular}{|c|c|c|c|c|c|c|c|c|c|}
\hline \multirow[t]{2}{*}{ Characteristics } & & \multicolumn{4}{|l|}{ OS } & \multicolumn{4}{|l|}{ BCSS } \\
\hline & & Univariate & $P$ & Multivariate & $P$ & Univariate & $P$ & Multivariate & $P$ \\
\hline \multirow{2}{*}{$\begin{array}{l}\text { Year of } \\
\text { diagnosis }\end{array}$} & 2004-2009 & Ref. & Ref. & Ref. & Ref. & Ref. & Ref. & Ref. & Ref. \\
\hline & 2010-2014 & $\begin{array}{l}0.898(0.619- \\
1.302)\end{array}$ & 0.571 & $\begin{array}{l}0.989(0.675- \\
1.450)\end{array}$ & 0.955 & $\begin{array}{l}0.870(0.548- \\
1.381)\end{array}$ & 0.554 & $\begin{array}{l}1.029(0.637- \\
1.661)\end{array}$ & 0.908 \\
\hline \multirow[t]{2}{*}{ Age (years) } & $20-49$ & Ref. & Ref. & Ref. & Ref. & Ref. & Ref. & Ref. & Ref. \\
\hline & $50-80$ & $\begin{array}{l}1.385(0.907- \\
2.117)\end{array}$ & 0.132 & $\begin{array}{l}1.514(0.962- \\
2.383)\end{array}$ & 0.073 & $\begin{array}{l}0.956(0.580- \\
1.576)\end{array}$ & 0.860 & $\begin{array}{l}1.175(0.688- \\
2.005)\end{array}$ & 0.555 \\
\hline \multirow[t]{3}{*}{ Race } & White & Ref. & Ref. & Ref. & Ref. & Ref. & Ref. & Ref. & Ref. \\
\hline & Black & $\begin{array}{l}1.135(0.696- \\
1.851)\end{array}$ & 0.613 & $\begin{array}{l}1.211(0.720- \\
2.036)\end{array}$ & 0.470 & $\begin{array}{l}1.065(.562- \\
2.020)\end{array}$ & 0.846 & $\begin{array}{l}1.127(0.527- \\
2.223)\end{array}$ & 0.729 \\
\hline & Other & $\begin{array}{l}1.048(0.510- \\
2.153)\end{array}$ & 0.898 & $\begin{array}{l}0.984(0.470- \\
2.058)\end{array}$ & 0.966 & $\begin{array}{l}0.886(0.323- \\
2.435)\end{array}$ & 0.815 & $\begin{array}{l}0.827(0.295- \\
2.317)\end{array}$ & 0.718 \\
\hline \multirow[t]{2}{*}{ Marital status } & Married & Ref. & Ref. & Ref. & Ref. & Ref. & Ref. & Ref. & Ref. \\
\hline & Not married & $\begin{array}{l}1.112(0.778- \\
1.590)\end{array}$ & 0.560 & $\begin{array}{l}0.888(0.604- \\
1.305)\end{array}$ & 0.546 & $\begin{array}{l}1.063(0.670- \\
1.686)\end{array}$ & 0.795 & $\begin{array}{l}0.883(0.537- \\
1.450)\end{array}$ & 0.623 \\
\hline \multirow[t]{4}{*}{ Grade } & 1 & Ref. & Ref. & Ref. & Ref. & Ref. & Ref. & Ref. & Ref. \\
\hline & ॥ & $\begin{array}{l}1.294(0.292- \\
5.735)\end{array}$ & 0.734 & $\begin{array}{l}1.054(0.230- \\
4.821)\end{array}$ & 0.946 & $\begin{array}{l}1.398(0.172- \\
11.366)\end{array}$ & 0.754 & $\begin{array}{l}0.963(0.114- \\
8.111)\end{array}$ & 0.972 \\
\hline & III & $\begin{array}{l}1.218(0.301- \\
4.935)\end{array}$ & 0.782 & $\begin{array}{l}1.144(0.269- \\
4.854)\end{array}$ & 0.856 & $\begin{array}{l}1.518(0.211- \\
10.938)\end{array}$ & 0.679 & $\begin{array}{l}0.875(0.115- \\
6.687)\end{array}$ & 0.898 \\
\hline & IV & $\begin{array}{l}2.472(0.534- \\
11.448)\end{array}$ & 0.247 & $\begin{array}{l}2.066(0.427- \\
9.992)\end{array}$ & 0.367 & $\begin{array}{l}2.845(0.322- \\
24.361)\end{array}$ & 0.340 & $\begin{array}{l}1.722(0.191- \\
15.555)\end{array}$ & 0.629 \\
\hline \multirow[t]{3}{*}{$\begin{array}{l}\text { Tumor size } \\
(\mathrm{cm})\end{array}$} & $<2$ & Ref. & Ref. & Ref. & Ref. & Ref. & Ref. & Ref. & Ref. \\
\hline & $\geqq 2$ and $<5$ & $\begin{array}{l}1.741(1.139- \\
2.661)\end{array}$ & 0.010 & $\begin{array}{l}2.266(1.436- \\
3.576)\end{array}$ & $<0.001$ & $\begin{array}{l}3.272(1.675- \\
6.391)\end{array}$ & 0.001 & $\begin{array}{l}3.554(1.760- \\
7.177)\end{array}$ & $<0.001$ \\
\hline & $\geqq 5$ & $\begin{array}{l}3.778(1.956- \\
7.296)\end{array}$ & $<0.001$ & $\begin{array}{l}5.593(2.682- \\
11.664)\end{array}$ & $<0.001$ & $\begin{array}{l}7.486(3.041- \\
18.431)\end{array}$ & $<0.001$ & $\begin{array}{l}7.159(2.668- \\
19.209)\end{array}$ & $<0.001$ \\
\hline \multirow[t]{4}{*}{ Nodal status } & NO & Ref. & Ref. & Ref. & Ref. & Ref. & Ref. & Ref. & Ref. \\
\hline & N1 & $\begin{array}{l}1.227(0.744- \\
2.023)\end{array}$ & 0.423 & $\begin{array}{l}1.350(0.803- \\
2.269)\end{array}$ & 0.257 & $\begin{array}{l}1.870(1.059- \\
3.304)\end{array}$ & 0.031 & $\begin{array}{l}1.752(0.973- \\
3.155)\end{array}$ & 0.062 \\
\hline & N2 & $\begin{array}{l}2.476(0.912- \\
6.723)\end{array}$ & 0.075 & $\begin{array}{l}2.637(0.904- \\
7.697)\end{array}$ & 0.076 & $\begin{array}{l}4.482(1.626- \\
12.356)\end{array}$ & 0.004 & $\begin{array}{l}4.276(1.386- \\
13.187)\end{array}$ & 0.011 \\
\hline & N3 & $\begin{array}{l}16.380(5.869- \\
45.714)\end{array}$ & $<0.001$ & $\begin{array}{l}16.437(5.575- \\
48.459)\end{array}$ & $<0.001$ & $\begin{array}{l}18.923(5.754- \\
62.230)\end{array}$ & $<0.001$ & $\begin{array}{l}20.504(5.729- \\
73.391)\end{array}$ & $<0.001$ \\
\hline \multirow[t]{2}{*}{ ER } & Positive & Ref. & Ref. & Ref. & Ref. & Ref. & Ref. & Ref. & Ref. \\
\hline & Negative & $\begin{array}{l}1.088(0.675- \\
1.752)\end{array}$ & 0.730 & $\begin{array}{l}1.043(0.615- \\
1.771)\end{array}$ & 0.875 & $\begin{array}{l}1.140(0.617- \\
2.110)\end{array}$ & 0.675 & $\begin{array}{l}1.205(0.596- \\
2.436)\end{array}$ & 0.604 \\
\hline \multirow[t]{2}{*}{ PR } & Positive & Ref. & Ref. & Ref. & Ref. & Ref. & Ref. & Ref. & Ref. \\
\hline & Negative & $\begin{array}{l}1.260(0.710- \\
2.234)\end{array}$ & 0.430 & $\begin{array}{l}1.061(0.558- \\
2.019)\end{array}$ & 0.856 & $\begin{array}{l}1.096(0.547- \\
2.194)\end{array}$ & 0.796 & $\begin{array}{l}0.908(0.407- \\
2.027)\end{array}$ & 0.814 \\
\hline \multirow[t]{2}{*}{ Chemotherapy } & yes & Ref. & Ref. & Ref. & Ref. & Ref. & Ref. & Ref. & Ref. \\
\hline & no & $\begin{array}{l}1.573(1.082- \\
2.289)\end{array}$ & 0.018 & $\begin{array}{l}2.253(1.457- \\
3.485)\end{array}$ & $<0.001$ & $\begin{array}{l}0.786(0.441- \\
1.400)\end{array}$ & 0.413 & $\begin{array}{l}1.318(0.688- \\
2.525)\end{array}$ & 0.405 \\
\hline \multirow[t]{2}{*}{$\begin{array}{l}\text { Surgical } \\
\text { method }\end{array}$} & BCS+RT & $\begin{array}{l}0.701(0.496- \\
0.990)\end{array}$ & 0.044 & $\begin{array}{l}0.684(0.479- \\
0.977)\end{array}$ & 0.037 & $\begin{array}{l}0.739(0.474- \\
1.153)\end{array}$ & 0.183 & $\begin{array}{l}0.741(0.468- \\
1.173)\end{array}$ & 0.200 \\
\hline & Mastectomy & Ref. & Ref. & Ref. & Ref. & Ref. & Ref. & Ref. & Ref. \\
\hline
\end{tabular}


OS= overall survival; $\mathrm{BCSS}$ = breast cancer-specific survival;PSM= propensity score matching

Table 4 Stratified analysis of OS and BCSS in univariate and multivariate analysis after PSM

\begin{tabular}{|c|c|c|c|c|c|c|c|c|c|}
\hline \multirow[t]{2}{*}{ Characteristics } & & \multicolumn{4}{|l|}{ OS } & \multicolumn{4}{|l|}{ BCSS } \\
\hline & & Univariate & $P$ & Multivariate & $P$ & Univariate & $P$ & Multivariate & $P$ \\
\hline \multirow[t]{2}{*}{$\begin{array}{l}\text { Year of } \\
\text { diagnosis }\end{array}$} & $\begin{array}{l}2004- \\
2009\end{array}$ & $\begin{array}{l}0.667(0.423- \\
1.051)\end{array}$ & 0.081 & $\begin{array}{l}0.647(0.409- \\
1.024)\end{array}$ & 0.063 & $\begin{array}{l}0.932(0.512- \\
1.697)\end{array}$ & 0.819 & $\begin{array}{l}0.928(0.506- \\
1.700)\end{array}$ & 0.808 \\
\hline & $\begin{array}{l}2010- \\
2014\end{array}$ & $\begin{array}{l}0.747(0.438- \\
1.274)\end{array}$ & 0.284 & $\begin{array}{l}0.720(0.418- \\
1.241)\end{array}$ & 0.237 & $\begin{array}{l}0.549(0.278- \\
1.085)\end{array}$ & 0.084 & $\begin{array}{l}0.533(0.268- \\
1.062)\end{array}$ & 0.074 \\
\hline \multirow[t]{2}{*}{ Age (years) } & $20-49$ & $\begin{array}{l}0.360(0.158- \\
0.823)\end{array}$ & 0.015 & $\begin{array}{l}0.350(0.151- \\
0.813)\end{array}$ & 0.015 & $\begin{array}{l}0.429(0.173- \\
1.063)\end{array}$ & 0.068 & $\begin{array}{l}0.459(0.181- \\
1.163)\end{array}$ & 0.101 \\
\hline & $50-79$ & $\begin{array}{l}0.830(0.565- \\
1.221)\end{array}$ & 0.345 & $\begin{array}{l}0.789(0.534- \\
1.165)\end{array}$ & 0.233 & $\begin{array}{l}0.890(0.532- \\
1.491)\end{array}$ & 0.659 & $\begin{array}{l}0.847(0.502- \\
1.429)\end{array}$ & 0.533 \\
\hline \multirow[t]{3}{*}{ Race } & White & $\begin{array}{l}0.594(0.400- \\
0.880)\end{array}$ & 0.009 & $\begin{array}{l}0.570(0.383- \\
0.849)\end{array}$ & 0.006 & $\begin{array}{l}0.595(0.360- \\
0.983)\end{array}$ & 0.043 & $\begin{array}{l}0.595(0.358- \\
0.987)\end{array}$ & 0.054 \\
\hline & Black & $\begin{array}{l}1.362(0.536- \\
3.460)\end{array}$ & 0.517 & $\begin{array}{l}1.175(0.436- \\
3.164)\end{array}$ & 0.750 & $\begin{array}{l}2.168(0.575- \\
8.176)\end{array}$ & 0.253 & $\begin{array}{l}1.797(0.422- \\
7.641)\end{array}$ & 0.428 \\
\hline & Other & $\begin{array}{l}1.178(0.290- \\
4.788)\end{array}$ & 0.819 & $\begin{array}{l}2.713(0.285- \\
25.823)\end{array}$ & 0.385 & $\begin{array}{l}1.441(0.203- \\
10.239)\end{array}$ & 0.715 & $\begin{array}{l}21.271(0.000- \\
3.688)\end{array}$ & 0.964 \\
\hline \multirow[t]{2}{*}{ Marital status } & Married & $\begin{array}{l}0.718(0.466- \\
1.105)\end{array}$ & 0.132 & $\begin{array}{l}0.662(0.426- \\
1.027)\end{array}$ & 0.066 & $\begin{array}{l}0.765(0.440- \\
1.329)\end{array}$ & 0.341 & $\begin{array}{l}0.698(0.397- \\
1.227)\end{array}$ & 0.211 \\
\hline & $\begin{array}{l}\text { Not } \\
\text { married }\end{array}$ & $\begin{array}{l}0.678(0.380- \\
1.209)\end{array}$ & 0.187 & $\begin{array}{l}0.736(0.407- \\
1.334)\end{array}$ & 0.313 & $\begin{array}{l}0.694(0.328- \\
1.468)\end{array}$ & 0.339 & $\begin{array}{l}0.713(0.334- \\
1.526)\end{array}$ & 0.384 \\
\hline \multirow[t]{2}{*}{ Grade } & $|+| \mid$ & $\begin{array}{l}0.958(0.346- \\
2.650)\end{array}$ & 0.934 & $\begin{array}{l}1.050(0.313- \\
3.525)\end{array}$ & 0.937 & $\begin{array}{l}0.655(0.156- \\
2.751)\end{array}$ & 0.564 & $\begin{array}{l}0.361(0.058- \\
2.242)\end{array}$ & 0.274 \\
\hline & III+IV & $\begin{array}{l}0.689(0.477- \\
0.995)\end{array}$ & 0.047 & $\begin{array}{l}0.666(0.460- \\
0.965)\end{array}$ & 0.032 & $\begin{array}{l}0.760(0.476- \\
1.214)\end{array}$ & 0.251 & $\begin{array}{l}0.738(0.461- \\
1.182)\end{array}$ & 0.206 \\
\hline \multirow[t]{3}{*}{$\begin{array}{l}\text { Tumor size } \\
(\mathrm{cm})\end{array}$} & $<2$ & $\begin{array}{l}0.780(0.370- \\
1.642)\end{array}$ & 0.513 & $\begin{array}{l}0.800(0.368- \\
1.737)\end{array}$ & 0.573 & $\begin{array}{l}0.408(0.105- \\
1.583)\end{array}$ & 0.195 & $\begin{array}{l}0.451(0.111- \\
1.839)\end{array}$ & 0.267 \\
\hline & $\begin{array}{l}\geqq 2 \\
\text { and }<5\end{array}$ & $\begin{array}{l}0.641(0.421- \\
0.976)\end{array}$ & 0.038 & $\begin{array}{l}0.602(0.393- \\
0.923)\end{array}$ & 0.020 & $\begin{array}{l}0.762(0.458- \\
1.268)\end{array}$ & 0.295 & $\begin{array}{l}0.757(0.452- \\
1.266)\end{array}$ & 0.288 \\
\hline & $\geqq 5$ & $\begin{array}{l}0.755(0.252- \\
2.257)\end{array}$ & 0.615 & $\begin{array}{l}0.688(0.165- \\
2.869)\end{array}$ & 0.607 & $\begin{array}{l}0.843(0.225- \\
3.154)\end{array}$ & 0.800 & $\begin{array}{l}0.850(0.152- \\
4.735)\end{array}$ & 0.852 \\
\hline \multirow[t]{2}{*}{ Nodal status } & $\mathrm{N}-$ & $\begin{array}{l}0.712(0.484- \\
1.048)\end{array}$ & 0.085 & $\begin{array}{l}0.690(0.469- \\
1.016)\end{array}$ & 0.060 & $\begin{array}{l}0.759(0.450- \\
1.280)\end{array}$ & 0.302 & $\begin{array}{l}0.722(0.428- \\
1.220)\end{array}$ & 0.224 \\
\hline & $\mathrm{N}+$ & $\begin{array}{l}0.650(0.295- \\
1.433)\end{array}$ & 0.285 & $\begin{array}{l}0.505(0.218- \\
1.172)\end{array}$ & 0.112 & $\begin{array}{l}0.718(0.307- \\
1.679)\end{array}$ & 0.444 & $\begin{array}{l}0.683(0.284- \\
1.647)\end{array}$ & 0.396 \\
\hline \multirow[t]{2}{*}{ ER } & Positive & $\begin{array}{l}0.328(0.119- \\
0.903)\end{array}$ & 0.031 & $\begin{array}{l}0.291(0.102- \\
0.827)\end{array}$ & 0.021 & $\begin{array}{l}0.334(0.090- \\
1.233)\end{array}$ & 0.100 & $\begin{array}{l}0.284(0.073- \\
1.108)\end{array}$ & 0.070 \\
\hline & Negative & $\begin{array}{l}0.797(0.549- \\
1.158)\end{array}$ & 0.235 & $\begin{array}{l}0.788(0.541- \\
1.148)\end{array}$ & 0.215 & $\begin{array}{l}0.842(0.521- \\
1.360)\end{array}$ & 0.482 & $\begin{array}{l}0.829(0.511- \\
1.344)\end{array}$ & 0.446 \\
\hline \multirow[t]{2}{*}{ PR } & Positive & $\begin{array}{l}0.357(0.109- \\
1.165)\end{array}$ & 0.088 & $\begin{array}{l}0.254(0.067- \\
0.969)\end{array}$ & 0.063 & $\begin{array}{l}0.240(0.050- \\
1.159)\end{array}$ & 0.076 & $\begin{array}{l}0.173(0.032- \\
0.921)\end{array}$ & 0.055 \\
\hline & Negative & $\begin{array}{l}0.750(0.522- \\
1.079)\end{array}$ & 0.122 & $\begin{array}{l}0.709(0.490- \\
1.024)\end{array}$ & 0.067 & $\begin{array}{l}0.838(0.524- \\
1.341)\end{array}$ & 0.461 & $\begin{array}{l}0.800(0.497- \\
1.288)\end{array}$ & 0.359 \\
\hline \multirow[t]{2}{*}{ Chemotherapy } & yes & $\begin{array}{l}0.598(0.393- \\
0.909)\end{array}$ & 0.016 & $\begin{array}{l}0.581(0.380- \\
0.887)\end{array}$ & 0.012 & $\begin{array}{l}0.765(0.469- \\
1.274)\end{array}$ & 0.282 & $\begin{array}{l}0.751(0.458- \\
1.230)\end{array}$ & 0.255 \\
\hline & no & $\begin{array}{l}0.986(0.525- \\
1.854)\end{array}$ & 0.966 & $\begin{array}{l}1.078(0.544- \\
2.137)\end{array}$ & 0.829 & $\begin{array}{l}0.646(0.223- \\
1.868)\end{array}$ & 0.420 & $\begin{array}{l}0.538(0.166- \\
1.749)\end{array}$ & 0.303 \\
\hline
\end{tabular}

OS= overall survival; BCSS = breast cancer-specific survival;PSM= propensity score matching 
Figures

A

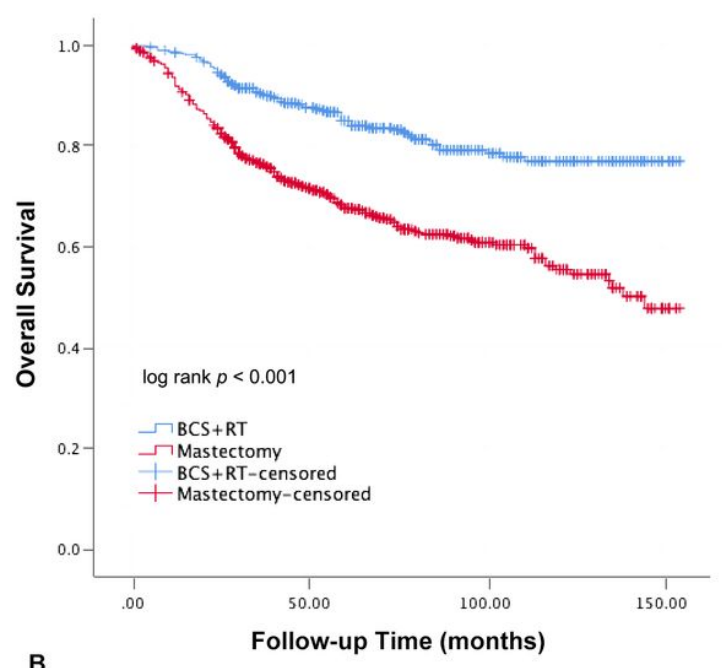

B

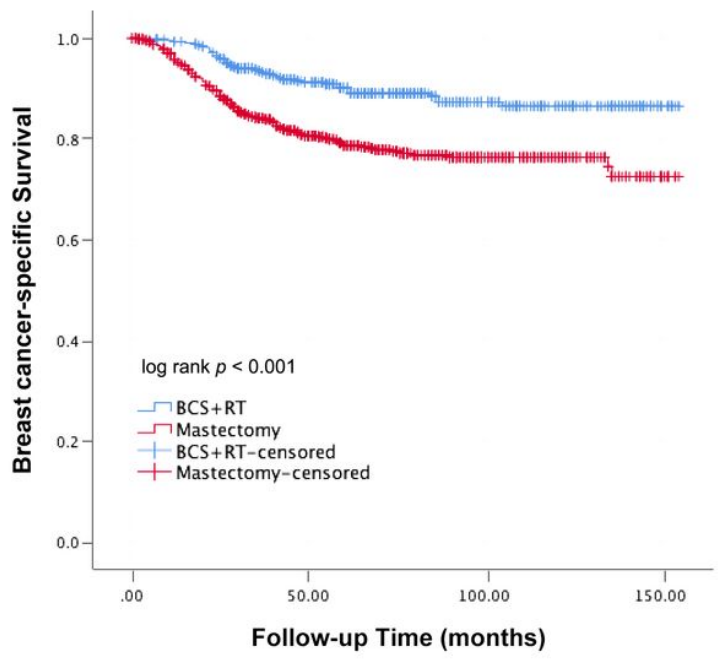

\section{Figure 1}

Kaplan-Meier curves of OS (A) and BCSS (B) for unmatched cohorts 
A

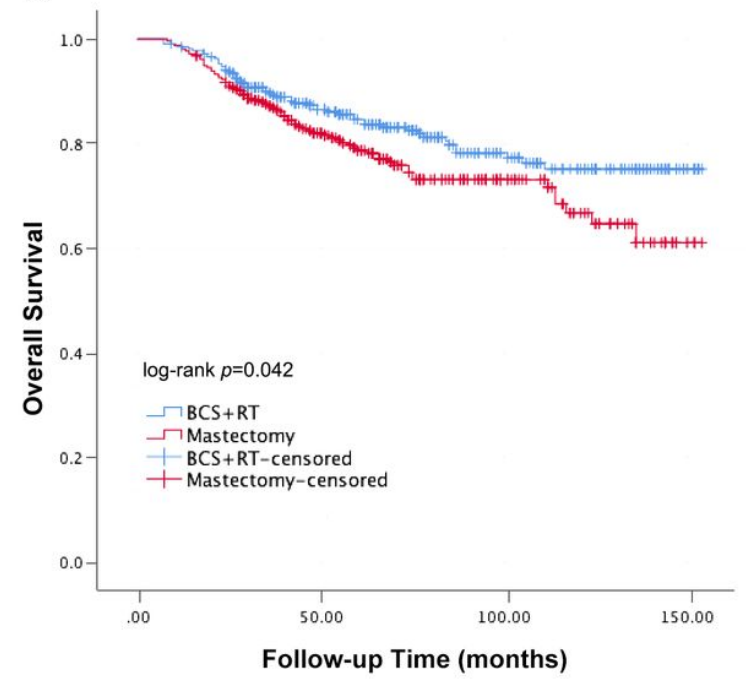

B

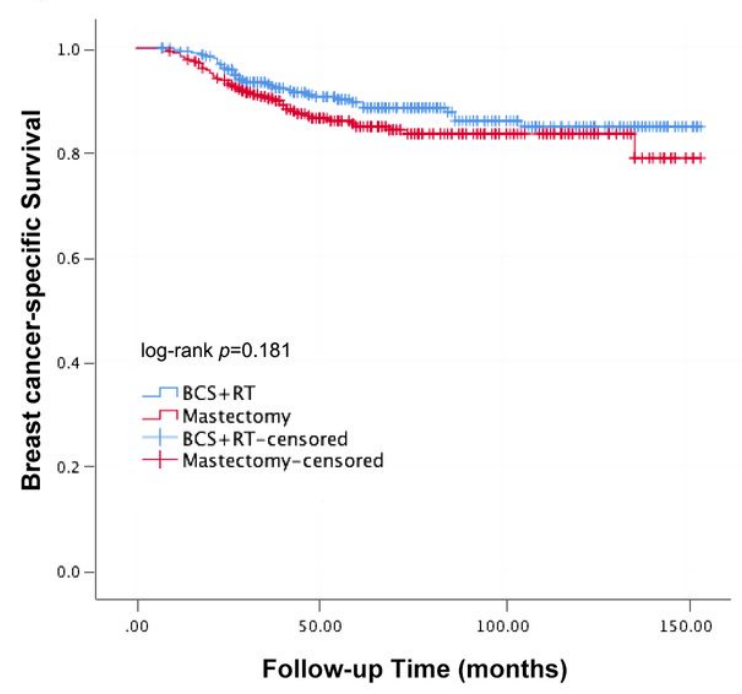

Figure 2

Kaplan-Meier curves of OS (A) and BCSS (B) : propensity matched landmark analysis

\section{Supplementary Files}

This is a list of supplementary files associated with this preprint. Click to download.

- supplementaryFigure1.jpg 